\title{
Capital Structure on Agency Costs: Evidence from Indian Public Companies
}

\author{
Rakesh H M, Lakshmi P \\ Asst. Professor Dept. of Business Administration Vidyavardhaka College Engineering, Mysore \\ Associate Professor Dept. of Business Administration Vidyavardhaka College Engineering, Mysore
}

\begin{abstract}
The study aims to provide empirical evidence on the agency costs hypothesis which suggests that increase of leverage may reduce agency costs. Multivariate tests have been employed in this study. The multivariate test tries to reveal the general relationship between leverage and agency costs which is usually negative. The study further tries to assess whether agency costs are significantly different when a firm has a relatively higher debt to asset ratio from when it is less leveraged. Similar supporting evidence is found for the agency costs hypothesis.
\end{abstract}

Keywords: Agency Cost, Leverage, Multivariate Test.

\section{Introduction}

In their seminal work, Jensen and Meckling (1976) point out that agency costs occur due to incomplete alignment of the agent's and the owner's interests. The separation of ownership and control may generate agency costs. Two types of agency costs are identified in the paper by Jensen and Meckling (1976): agency costs derived from conflicts between outside equity holders and owner-managers, and conflicts between equity holders and debt holders. From then on, a great amount of research has been devoted to demonstrate the interaction between agency costs and financial decisions, governance decisions, dividend policy, and capital structure decisions.

However, as the proportion of debt in the capital structure increases beyond a certain point, the opposite effect of leverage on agency costs may occur (Altman, 1984 and Titman, 1984). When leverage becomes relatively high, further increases may generate significant agency costs. Three reasons are identified in the literature which can cause this opposite effect: first reason is the increase of bankruptcy costs (Titman 1984). Second reason is that managers may reduce their effort to control risk which result in higher expected costs of financial distress, bankruptcy, or liquidation (Berger and Bonaccorsi di Patti, 2005). Finally, inefficient use of excessive cash used by managers for empire building would also increase agency costs (Jensen, 1986).

\section{Literature review}

Jensen and Meckling (1976) identify agency costs derived from conflicts between equity holders and owner-managers as "residual loss" which means agent consumes various pecuniary and non-pecuniary benefits from the firm to maximize his own utility. Related to this issue, Harris \&Raviv (1990), Childs et al. (2005) and Lee et al. (2004) argue that managers always want to continue firm's current operations even if liquidation of the firm is preferred by investors. Also, Stulz (1990), Alvarez et al. (2006) and Kent et al. (2004) suggest the manager always want to invest all available funds even if paying out cash is better for outside shareholders, and conflict between the manager and equity holders cannot be resolved through contracts based on cash flows and investment expenditures.

Agency theory becomes more complicated when debt holders' interest is considered. As a financing strategy, debt is widely discussed in capital structure literatures. Modigliani and Miller (1963) demonstrate that in order to raise the value of a firm, the amount of debt financing should be as big as possible for tax subsidy. However, their theory ignores the agency costs of debt. Theoretically, Jensen and Meckling (1976) point out that the optimal utilization of debt is when the debt is utilized to the point where marginal wealth benefits of the tax subsidy are just equal to the marginal wealth effects of agency costs.

\section{Data and methodology}

Data used in this study are drawn from top 20 Companies from FTSE ALL SHARE index. We have considered Indian public companies in this study because of three reasons: First, The India is a country with matured money and capital markets where debt financing is relatively easy to conduct by companies. Second, maximization of shareholders' wealth is the dominant goal of management in India which is consistent with the theory this study is based on. Third, data of public companies could reflect the effect of leverage on agency costs more accurately and sensitively especially in the efficient markets like India. The following are the variables considered for the study. 
Table 1: Variable Definitions

\begin{tabular}{|l|l|}
\hline Variables & Definition \\
\hline Operating expenses to Sales & Operating expenses divided by sales \\
\hline Debt-Asset ratio & Debt divided by total assets \\
\hline Log of Sales & Natural log od annual sales \\
\hline Return on assets & Return on assets \\
\hline
\end{tabular}

Table 2: Descriptive statistic of variables used to analyze agency costs

\begin{tabular}{|l|l|l|l|l|l|l|}
\hline Particulars & Mean & Maximum & Minimum & $\begin{array}{l}\text { Standard } \\
\text { Deviation }\end{array}$ & Skewness & Excess \\
\hline Panel A: 2011 (N=20) & & & & & & \\
\hline Operating expenses to Sales & 0.24 & 0.92 & 0.02 & 0.17 & 1.15 & 1.07 \\
\hline Debt-Asset ratio & 0.23 & 1.22 & 0 & 0.22 & 1.39 & 2.78 \\
\hline Log of Sales & 12.86 & 18.74 & 8.87 & 1.67 & 0.46 & 0.34 \\
\hline Return on assets & 0.07 & 0.64 & -0.64 & 0.13 & -1.85 & 10.63 \\
\hline & & & & & & \\
\hline Panel B: 2012 (N=20) & & & & & 0.18 & 1.14 \\
\hline Operating expenses to Sales & 0.24 & 0.95 & 0.02 & 0.18 & 0.92 & 1.09 \\
\hline Debt-Asset ratio & 0.23 & 0.84 & 0 & 1.64 & 0.55 & 0.31 \\
\hline Log of Sales & 12.99 & 18.87 & 9.73 & 0.14 & -2.19 & 17.93 \\
\hline Return on assets & 0.07 & 0.42 & -0.83 & & & \\
\hline
\end{tabular}

The descriptive statistics for the sample of 20 Indian public companies for 2011 and 2012 are presented in Table 2. The mean value of the operating expenses to sales of the sample firms is 0.24 for both 2011 and 2012.Highest and lowest values of this ratio are 0.92 and 0.02 for 2011, 2012 respectively. Normality test also is undertaken for 2011 and 2012. The results $\left(\mathrm{Chi}^{\wedge} 2(2)=134.63\right.$ for 2011 and $\mathrm{Chi}^{\wedge} 2(2)=134.13$ for 2012$)$ suggest that the OETS is not normally distributed.

Table: 3

\begin{tabular}{|l|l|l|}
\hline Years & $\begin{array}{l}\text { Debt to Asset ratio } \\
\text { \% }\end{array}$ & $\begin{array}{l}\text { Operating expenses to } \\
\text { sales \% }\end{array}$ \\
\hline 2002 & 22.63 & 16.86 \\
\hline 2003 & 14.19 & 20.62 \\
\hline 2004 & 14.35 & 12.04 \\
\hline 2005 & 14.92 & 11.29 \\
\hline 2006 & 31.01 & 9.83 \\
\hline 2007 & 27.36 & 9.71 \\
\hline 2008 & 47.89 & 8.1 \\
\hline 2009 & 47.63 & 8.68 \\
\hline 2010 & 46.22 & 8.35 \\
\hline 2011 & 46.18 & 7.59 \\
\hline 2012 & 46.71 & 9.75 \\
\hline
\end{tabular}

\section{Multivariate Tests}

\section{Results and analysis}

The main purpose of the test is to assess the general relation between agency costs and leverage, and whether this relation is statistically significant. As suggested by the agency costs hypothesis, the relation is expected to be negative.

Table: 4 Correlation Coefficients Matrix

\begin{tabular}{|c|c|c|c|c|}
\hline Particulars & $\begin{array}{l}\text { Operating } \\
\text { expenses to } \\
\text { Sales }\end{array}$ & $\begin{array}{l}\text { Debt-Asset } \\
\text { ratio }\end{array}$ & $\begin{array}{ll}\text { Log } & \text { of } \\
\text { Sales } & \end{array}$ & $\begin{array}{l}\text { Return on } \\
\text { assets }\end{array}$ \\
\hline \multicolumn{5}{|l|}{ Panel A: $2011(\mathrm{~N}=20)$} \\
\hline Operating expenses to Sales & 1 & & & \\
\hline Debt-Asset ratio & -0.0652 & 1 & & \\
\hline Log of Sales & -0.2602 & -0.0224 & 1 & \\
\hline
\end{tabular}




\begin{tabular}{|l|l|l|l|l|} 
Return on assets & -0.0116 & 0.0353 & 0.0054 & 1 \\
\hline & & & & \\
\hline Panel B: 2012 (N=20) & & & & \\
\hline Operating expenses to Sales & 1 & & & \\
\hline Debt-Asset ratio & -0.0914 & 1 & & \\
\hline Log of Sales & -0.2588 & -0.0083 & 1 & 1 \\
\hline Return on assets & -0.0343 & -0.0763 & 0.0354 & \\
\hline
\end{tabular}

Before running the regressions, we first consider the correlations among variables in the regressions. Two correlation coefficient matrixes are presented in Table 5. Obviously, there is a negative relation between OETS and DTAR both in Year 2011 and 2012, which is consistent with the agency costs hypothesis. The correlation coefficients are -0.0652 and -0.0914 respectively.

Additionally, OETS is negatively related with LOS and ROA with correlation coefficients of -0.2602 and -0.0116 in Year 2011, - 0.2588 and -0.0343 in Year 2012. What's more, as the values of correlation coefficients are all below 0.5 in the absolute term, there should be not much evidence of sever multicollinearity amongst the variables. Therefore, a linear regression is employed for the multivariate tests.

Table: 5 Variables Used in the Linear Regression

\begin{tabular}{|c|c|c|c|c|}
\hline Particulars & Model 3 & Model 4 & Model 5 & Model 6 \\
\hline \multicolumn{5}{|c|}{ Panel A: $2011(N=20)$} \\
\hline Significance Value & 0.26 & 0.62 & 0.25 & 0.63 \\
\hline t-value & $(16.5)$ & $(8.08)$ & $(20.1)$ & $(8.11)$ \\
\hline Debt to asset ratio & -0.08 & & & -0.08 \\
\hline t-value & -1.76 & & & -1.73 \\
\hline Log of sales & & -0.02 & & -0.02 \\
\hline t-value & & -4.48 & & -4.86 \\
\hline Return on assets & & & -0.01 & -0.02 \\
\hline t-value & & & -0.19 & -0.14 \\
\hline RSS & 10.76 & 10 & 10.89 & 10.05 \\
\hline F value & 2.94 & 23.42 & 0.06 & 8.34 \\
\hline \multicolumn{5}{|c|}{ Panel B: $2012(\mathrm{~N}=20)$} \\
\hline Significance Value & 0.27 & 0.62 & 0.26 & 0.65 \\
\hline t-value & $(17.01)$ & $(8)$ & $(19.5)$ & $(8.24)$ \\
\hline Debt to asset ratio & -0.08 & & & -0.09 \\
\hline t-value & -1.63 & & & -1.74 \\
\hline Log of sales & & -0.03 & & -0.03 \\
\hline t-value & & -4.86 & & -4.86 \\
\hline Return on assets & & & -0.05 & -0.05 \\
\hline t-value & & & -0.61 & -0.59 \\
\hline RSS & 10.73 & 10.13 & 10.75 & 10.08 \\
\hline F value & 2.75 & 24.81 & 0.45 & 8.89 \\
\hline
\end{tabular}

Table 5 reports the results for multivariate regression (3) and the simple regression (4)-(6). Column 1 identifies the explanatory variables and column 2 to 5 is the parameter estimates for the regressions (3)-(6). In columns 2 through 4 the leverage and each control variables are analyzed independently.

In Column 5, the study tests whether the independent results stand up when all variables are included in a single regression, because of the importance of industry structure as discussed.

In Column 2, the relation between the leverage and agency costs is tested, the parameter estimates $-0.06(\mathrm{t}=\mathrm{-}$ $1.76, \mathrm{~F}=2.94)$ in Year 2011 and $-0.09(\mathrm{t}=-1.63, \mathrm{~F}=2.75)$ in Year 2012 suggest that there is an inverse relationship between agency costs and debt and total assets ratio as expected. This result supports the agency costs hypothesis, i.e., higher leverage can reduce agency costs. The coefficient is only $90 \%$ significantly different from zero. 
Similarly, Column 3 suggests that there is a significant negative relation between firm size and agency costs. Column 4 indicates a negative relation between agency costs and firm performance but the relation is not significant.

Column 5 gives the results of Model (6). The leverage coefficient exhibits the predicted negative sign, and the coefficient is still $90 \%$ significantly differently from zero. The firm size and firm performance coefficients exhibit the inverse relation with agency costs as well.

\section{Conclusion}

In this paper, we provide empirical evidence for the agency costs hypothesis by conducting the multivariate tests based on data on top 20 listed companies in India. In the multivariate tests, the negative relation between leverage and agency costs is confirmed. The results suggest that the inverse relation is significant at $10 \%$ level. In addition, it is found that the firm size is negative related to agency costs with a significant level of $1 \%$ and firm performance is inversely related to agency costs but insignificantly.

In sum, our empirical results appear to support the agency costs hypothesis.

\section{References}

[1]. Alvarez, H.; J. Virtanen, (2006), A class of solvable stochastic dividend optimization problems: on the general impact of flexibility on valuation, Economic Theory, 28 , pp373-398.

[2]. Ang, J.S.; R.A. Cole; Lin, J.W., (2000), Agency costs and ownership structure, Journal of Finance, 5, pp81-106.

[3]. Berger S., E. Banaccorsi di Patti, (2006), Capital Structure and firm performance: A new approach to testing agency theory and an application to the bank industry, Journal of Banking \& Finance, 30, pp1065-1102.

[4]. Bhattacharya, U.; B., Ravikumar, (2001), Capital markets and the evolution of family business, Journal of Business, 74, pp187219

[5]. Chance, D. M., (1997), A Derivate Alternative as Executive Compensation, Financial Analyst Journal, 53, pp36-78.

[6]. Cole, R.A.; H., Mehran, (1998), The effect of changes in ownership structure on performance: Evidence from the thrift industry, Journal of Financial Economics, 50, pp291-317.

[7]. Donald, G.; T. Burk; H. Alan, (2003), Innovation in Small Businesses: Culture and Ownership Structure Do Matter, Journal of Developmental Entrepreneurship, 8, pp1-31.

[8]. DeMarzo, P., M., Fishman, (2007), Agency and Optimal Investment Dynamics, The Review of Financial Studies, 20(1), pp151-188

[9]. Demsetz, H.; K. Warther, (1998), Dividends, asymmetric information, and agency conflicts: Evidence from a comparison of the dividend policies of Japanese and USA firms, Journal of Finance 53, pp879-904.

[10]. Drew, A.; C. Kelley; Kendrick, T., (2005), CLASS: Five elements of corporate governance to manage strategic risk, Business Horizons, 49, 2, pp127-138.

[11]. Fama, E.; M.C Jensen, (1983), Separation of ownership and control, Journal of Law and Economics, 26, pp301-325.

[12]. Fleming, G.; R. Heaney; R. McCosker, (2005), Agency costs and ownership structure in Australia, Pacific-Basin Finance Journal, 13, pp29-52.

[13]. Grossman, S.J.;O.Hart, (1982), Corporate financial structure and managerial incentives. The economics of information and uncertainty, University of Chicago Press, pp128-146.

[14]. Harris, M.; A. Raviv, (1990), Capital structure and the informational role of debt, Journal of Finance, 45, pp321-349.

[15]. Harris, M.; A. Raviv, (1990), The Theory of Capital Structure, Journal of Finance, 46, pp297-355.

[16]. Jensen, M. C.; W. H. Meckling, (1976), Theory of the firm: managerial behavior, agency costs and ownership structure, Journal of Financial Economics, 3, pp305-60. 